\title{
PHYTOCHEMICAL CONSTITUENTS, PHENOLIC CONTENTS, AND ANTIOXIDANT ACTIVITY OF CRATAEGUS AZAROLUS EXTRACTS
}

\author{
BOUDJADA AMINA ${ }^{1}$, TOUIL AHMED ${ }^{1 *}$, BENDIF HAMDI ${ }^{2}$, BENSOUICI CHAWKI ${ }^{3}$, RHOUATI SALAH ${ }^{1}$
}

${ }^{1}$ Laboratory of Natural Product from Plant and Organic Synthesis, Department of Chemistry, Faculty of Science, University of Mentouri-Constantine, Route Ain el-Bey, 25000, Constantine, Algeria. ${ }^{2}$ Department of Natural and Life Science, Faculty of Science, Mohamed Boudiaf University, BP 166 M'sila 28000, Algeria. ${ }^{3}$ Centre de Recherche en Biotechnologie, Ali Mendjli, UV 03, BP E73, Constantine, Algeria. Email: Ahmedtouil@yahoo.fr

Received: 18 November 2017, Revised and Accepted: 23 December 2017

\section{ABSTRACT}

Objective: The aim of this study was the isolation and identification of secondary metabolites from Crataegus azarolus (L.) and the antioxidant evaluation of its extracts and compounds.

Methods: The air-dried powdered parts of the plant were extracted with 70\% methanol and fractionated by chloroform, ethyl acetate, and n-butanol. The n-butanol extract was separated using polyamide SC6 column and silica gel TLC. In addition, a fraction of silica gel column of the $\mathrm{CHCl}_{3}$ extract was analyzed by gas chromatography-mass spectrometer (GC-MS). The total phenolic and total flavonoid contents of $\mathrm{CHCl}_{3}$ and $\mathrm{n}$-butanol extracts were estimated. Furthermore, the antioxidant activities of $\mathrm{CHCl}_{3}$, n-butanol extracts, and two flavonoids were evaluated according to five different methods.

Results: Eight compounds were identified in $\mathrm{CHCl}_{3}$ and n-butanol extracts, among them, five volatile compounds identified by GC-MS for the $1^{\text {st }}$ time from the species, as well as three known flavonol glycosides identified by spectral analysis (ultraviolet, ${ }^{1} \mathrm{H}$-nuclear magnetic resonance [NMR], and ${ }^{13} \mathrm{C}-\mathrm{NMR}$ ) and by comparison with literature data. The n-butanol extract showed the higher content of polyphenols (307.33 $\pm 2.33 \mathrm{mg}$ (gallic acid equivalents)/g extract) and flavonoids (143.0 $\pm 2.12 \mathrm{mg} \mathrm{QE} / \mathrm{g}$ extract) and it proves the highest antioxidant activity with all assays used.

Conclusion: Five volatile compounds were identified for the $1^{\text {st }}$ time from the C. azarolus and the antioxidant potential of plant extracts was measured using five different methods.

Keywords: Crataegus azarolus (L.), Volatile compounds, Flavonol glycosides, Phenolic contents, Antioxidant activity.

(c) 2018 The Authors. Published by Innovare Academic Sciences Pvt Ltd. This is an open access article under the CC BY license (http://creativecommons. org/licenses/by/4. 0/) DOI: http://dx.doi.org/10.22159/ajpcr.2018.v11i4.23724

\section{INTRODUCTION}

Crataegus species (Rosaceae) known as "Hawthorn" are shrubs or small tree usually with thorns with about 200 species commonly distributed throughout the Northern temperate region [1]. Crataegus extracts from leaves, flowers, and fruits are generally used for heart diseases such as hypertension, angina, arrhythmia, and congestive heart failure. In traditional Arabic medicine, the leaf and fruit extract of Crataegus aronia are used for cardiovascular diseases, sexual weakness, cancer, and diabetes treatment [2]. Some Crataegus species are currently officially listed as herbal drugs in the pharmacopeias of many countries such as France, China, England, and Germany [3-5]. The species Crataegus azarolus (L.) is a fruit tree cultivated in the Mediterranean region [6], it is known in the east of Algeria as "Zaarour" and its fresh fruits are consumed during the autumn season.

Previous phytochemical studies on C. azarolus have revealed the presence of polyphenols including flavonoids from the species collected from Tunisia [7-10] and volatile oils from the species from Algeria [11]. The present paper aimed at the exploration of the richness of secondary metabolites of $C$. azarolus as a possible source of compounds having beneficial biological activities as well as the evaluation of its antioxidant activity. As a result, eight compounds were identified from the plant, where five volatile compounds are reported for the first time from Crataegus genus with three flavonol glycosides, also the total phenolic content (TPC), total flavonoid content (TFC), and the antioxidant activity were evaluated.

\section{METHODS}

\section{Plant material}

Aerial parts of $C$. azarolus were collected from Mila region in the east of Algeria during flowering period in 2013. A voucher specimen was deposited under number CA 022 in our laboratory.

\section{Extraction and isolation}

Air-dried powdered aerial parts ( $300 \mathrm{~g}$ ) of C. azarolus were extracted 3 times with a solution of $70 \%$ methanol during $24 \mathrm{~h}$. The combined extracts were evaporated under reduced pressure and temperature. The residue was dissolved in hot distilled water $(300 \mathrm{ml})$, and left in cold overnight. After filtration, the aqueous extract was successively extracted by solvents with increasing polarity and evaporated under reduced pressure to yield chloroform ( $0.8 \mathrm{~g})$, ethyl acetate ( $1.2 \mathrm{~g})$, and n-butanol (8 g). The n-butanol extract ( $4 \mathrm{~g}$ ) was subjected to a polyamide SC6 column chromatography using $\mathrm{H}_{2} \mathrm{O}-\mathrm{MeOH}$ as the system of elution to give 100 fractions of $100 \mathrm{ml}$ each. Similar fractions were combined according to their TLC (cellulose) properties using 15\% HOAc ( $\mathrm{H}_{2} \mathrm{O}$-acetic acid, 85:15) and BAW (n-butanolacetic acid-water, 4:1:5, upper phase) as eluent to give 12 main fractions (A-L). Compounds 1 and 2 were separated from fraction $G$ by silica gel TLC using $\mathrm{CH}_{2} \mathrm{Cl}_{2}-\mathrm{MeOH}$ (9:1) as eluent, while compound 3 was obtained from fraction $\mathrm{L}$ as a yellow solid by repeated crystallization from methanol.

\section{Gas chromatography-mass spectrometer (GC-MS) analysis}

The chloroform extract ( $0.8 \mathrm{~g}$ ) was fractioned by a silica gel column, eluted with a gradient of cyclohexane-ethyl acetate with increasing 
polarity to give 10 main fractions (1-10). The fraction 3 (eluted with $20 \%$ ethyl acetate) was subjected to GC-MS analysis using a gas chromatograph VARIAN 3900 with CP-8400 autoinjector coupled to MS (VARIAN Saturn 2000 MS-MS). A Factor Four VF-5 ms fused silica capillary column (30 $\mathrm{m} \times 0.25 \mathrm{~mm}$ I.D., $0.25 \mu \mathrm{m}$, Varian $)$ was used. Oven temperature was programmed at $5^{\circ} \mathrm{C} / \mathrm{min}$. From $45^{\circ} \mathrm{C}$ to $280^{\circ} \mathrm{C}$, the oven was maintained at $280^{\circ} \mathrm{C}$ for $5 \mathrm{~min}$. The injector temperature was set at $230^{\circ} \mathrm{C}$ and $1 \mu \mathrm{l}$ aliquots were injected with a split ratio of $1: 10$. Helium was used as carrier gas with a flow rate of $1 \mathrm{ml} / \mathrm{min}$. The ion trap MS was operated in EI mode at $70 \mathrm{eV}$. The analyses were performed with a filament-multiplier delay of $9 \mathrm{~min}$ and data acquisition was done in the range $50-650 \mathrm{~m} / \mathrm{z}$ in full scan mode. The transfer line was maintained at $250^{\circ} \mathrm{C}$, the manifold and trap temperatures were set at $80^{\circ} \mathrm{C}$ and $150^{\circ} \mathrm{C}$, respectively. Instrument control and MS data were managed by a personal computer running the Saturn GC-MS WorkStation software (6.30 version). Identification of the chromatographic peaks of compounds (4-8) was realized by comparison of their mass spectra with those present in literature including a comparison with National Institute of Standards and Technology library (NIST).

\section{Biological studies}

$T P C$

Folin-Ciocalteu assay was carried out by the procedure [12], with minor modifications. Gallic acid solution at various concentrations was used for calibration (Table 1). The TPC of samples was expressed as gallic acid equivalents (mg GAE/g extract) by means of a dose-response curve for gallic acid $\left(Y=0.0051 \mathrm{x}+0.1731,\left(\mathrm{R}^{2}: 0.9964\right)\right)$

\section{TFC}

The TFC was based on the complexation with $\mathrm{Al}^{3+}$. Quercetin at various concentrations was used for calibration [13] (Table 1). The TFC of samples was expressed as quercetin equivalents (mg QE/g extract) by means of a dose-response curve for quercetin ( $Y=0.06648 x-0.01586,\left(R^{2}: 0.9972\right)$ ).

\section{Antioxidant activity}

Free radicals are regularly generated in the body during the metabolic process. Once the production of these free radicals in the body exceeds its antioxidant mechanism, they cause wide damage to the cells may lead to many degenerative diseases [14]. It is also known that plants extracts rich in polyphenols are having varying antioxidant activity and there are many methods to determine antioxidant capacity. These methods differ in terms of their assay principles and experimental conditions [15]. Therefore, the antioxidant activities of $C$. azarolus extracts, as well as two pure compounds were evaluated using five assays.

\section{Free radical scavenging activity by 2,2-diphenyl-picrylhydrazyl (DPPH) assay}

The DPPH assay was determined by the method described previously with some modifications $[16,17]$. A solution of $40 \mu \mathrm{l}$ of the sample (extracts, pure compounds, and standards) at various concentrations was added to $160 \mu \mathrm{l}$ of the methanolic solution of DPPH $(0.1 \mathrm{mM})$. Blanks were prepared using the solvent in addition to the DPPH reagent. After incubation at $37^{\circ} \mathrm{C}$ for $30 \mathrm{~min}$, the absorbance of each solution was determined at $517 \mathrm{~nm}$ using a microplate reader. Butyl hydroxyl toluene (BHT) and butyl hydroxyanisole (BHA) were used as standards for comparison of the activity. The free radical scavenging activity of each solution was calculated as percent inhibition according to the following equation:

$$
\% \text { Inhibition }=\left[\left(A_{\text {blank }}-A_{\text {sample }}\right) / A_{\text {blank }}\right] \times 100
$$

Where, $A_{\text {blank }}$ and $A_{\text {sample }}$ are the absorbance of initial and remaining concentrations of the DPPH in the presence of samples and standards, respectively. The extract concentration providing $50 \%$ radical scavenging activity half maximal inhibitory concentration $\left(\mathrm{IC}_{50}\right)$ was calculated from the graph of DPPH radical scavenging effect percentage against extract concentration (Table 2).

\section{2,2'-azino-bis-(3-ethylbenzothiazoline-6-sulfonic acid (ABTS) radical cation decolorization assay}

ABTS decolorization assay was determined by the method described previously [18]. ABTS $^{*+}$ solution was prepared by mixing $7 \mathrm{mM}$ of $\mathrm{ABTS}^{*+}$ in water with $2.45 \mathrm{mM}$ potassium persulfate. The mixture was left in the dark at room temperature for $12 \mathrm{~h}$ before use. The dilution of the obtained solution was adjusted to obtain the absorbance of $0.70 \pm 0.02$ at $734 \mathrm{~nm}$. Then, to $40 \mu \mathrm{l}$ of the sample solution in methanol at different concentrations was added $160 \mu \mathrm{l}$ of ABTS $^{*+}$ solution. The mixture was left at ambient temperature for $10 \mathrm{~min}$ and then the absorbance was measured at $734 \mathrm{~nm}$ using a 96-well microplate reader. The percentage inhibitions were calculated for each concentration relative to a blank absorbance (methanol). The scavenging capability of $\mathrm{ABTS}^{\bullet+}$ was calculated using the following equation:

$\%$ Scavenging effect $=\left[\left(A_{\text {blank }}-A_{\text {sample }}\right) / A_{\text {blank }}\right] \times 100$

Where, $A_{\text {blank }}$ is the initial concentration of the $\mathrm{ABTS}^{\bullet+}$ and $\mathrm{A}_{\text {sample }}$ is the absorbance of the remaining concentration of $\mathrm{ABTS}^{*+}$ in the presence of the sample. The extract concentration providing $50 \%$ radical scavenging activity $\left(\mathrm{IC}_{50}\right.$ ) was calculated from the graph of $\mathrm{ABTS}^{\bullet+}$ scavenging effect percentage against sample concentrations. BHT and BHA were used as antioxidant standards (Table 2).

\section{Cupric reducing antioxidant capacity (CUPRAC)}

The CUPRAC was determined according to the method described previously with minor changes $[17,19]$. To $50 \mu \mathrm{l}$ of $\mathrm{Cu}$ (II) solution $(10$ $\mathrm{mM}$ ) was added $50 \mu \mathrm{l}$ of neocuproine solution $(7.5 \mathrm{mM})$ and $60 \mu \mathrm{l}$ of $\mathrm{NH}_{4} \mathrm{Ac}$ buffer (1 M, pH 7.0) solution. To the above mixture was added, $40 \mu \mathrm{l}$ of the sample solutions (extracts and pure compounds) at different concentrations. After $60 \mathrm{~min}$, the absorbance at $450 \mathrm{~nm}$ was recorded against a reagent blank using a 96-well microplate reader. The results were given as $A_{05}(\mu \mathrm{g} / \mathrm{ml})$ corresponding to the concentration indicating $50 \%$ absorbance intensity and were compared with those of the standards BHA and BHT (Table 2).

\section{Reducing power assay}

The reducing power was measured with small changes according to $[17,20]$. Briefly, a solution $(10 \mu \mathrm{l})$ of the sample at various concentrations was mixed with $40 \mu \mathrm{l}$ of phosphate buffer $(0.2 \mathrm{M}, \mathrm{pH} 6.6)$ and $50 \mu \mathrm{l}$ of potassium ferricyanide $(10 \mathrm{mg} / \mathrm{ml})$. The obtained solution was incubated at $50 \mathrm{C}^{\circ}$ for $20 \mathrm{~min}$. Then, the solution was mixed with $50 \mu \mathrm{l}$ of trichloroacetic acid solution $(100 \mathrm{mg} / \mathrm{ml}), 10 \mu$ l of ferric chloride solution $(1.0 \mathrm{~g} / \mathrm{l})$, and finally diluted with $40 \mu \mathrm{l}$ of distilled water. The absorbance was measured at $700 \mathrm{~nm}$ using a 96-well microplate reader. Ascorbic acid, tannic acid, $\alpha$-tocopherol, BHA, and BHT were used as standards. The results were given as $A_{0.5}(\mu \mathrm{g} / \mathrm{ml})$ corresponding to the concentration indicating 50\% absorbance intensity (Table 2). The increase of reducing power by the extract and standard was calculated as follows:

$\%$ Reducing power $=\left[\left(A_{\text {test }} / A_{\text {blank }}\right)-1\right] \times 100$

Where, $A_{\text {test }}$ and $A_{\text {blank }}$ are absorbance of sample and blank solutions, respectively.

\section{$\beta$-carotene bleaching assay}

The assay was carried out as described previously with minor modifications $[17,21]$. A stock solution of $\beta$-carotene/linoleic acid was initially prepared by mixing a solution of $\beta$-carotene $(5 \mathrm{mg})$ in chloroform $(1 \mathrm{ml})$ with linoleic acid $(25 \mu \mathrm{l})$ and Tween 40 emulsifier (200 mg). The mixture was evaporated under vacuum to remove chloroform. Then, $100 \mathrm{ml}$ of water saturated with oxygen was added to the above mixture by agitation. A volume of $40 \mu \mathrm{l}$ of the samples (in ethanol) at different concentrations was mixed with $160 \mu$ l of the above 
Table 1: Total phenolic and flavonoid contents of $C$. azarolus extracts

\begin{tabular}{lll}
\hline Extract (1 $\mathbf{~ m g / m l )}$ & Phenolic content (mg GAE/g extract)* & Flavonoid content (mg QE/g extract)* \\
\hline Chloroform & $118.0 \pm 1.52$ & $7.33 \pm 0.47$ \\
n-butanol & $307.33 \pm 2.33$ & $143.0 \pm 2.12$ \\
\hline
\end{tabular}

*Values were expressed as means \pm SD. (n=3). SD: Standard deviation, C. azarolus: Crataegus azarolus, GAE: Gallic acid equivalent

Table 2: Antioxidant activities of chloroform, n-butanol extracts, and two compounds from C. azarolus

\begin{tabular}{|c|c|c|c|c|c|}
\hline Extract/Compound & 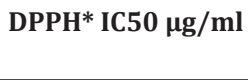 & $\begin{array}{l}\text { ABTS* } \\
\text { IC50 } \mu \mathrm{g} / \mathrm{ml}\end{array}$ & $\begin{array}{l}\text { CUPRAC* } \\
\text { A0.50 } \mu \mathrm{g} / \mathrm{ml}\end{array}$ & $\begin{array}{l}\text { Reducing power* } \\
\mathrm{A} 0.50 \mu \mathrm{g} / \mathrm{ml}\end{array}$ & $\begin{array}{l}\beta \text {-carotene* } \\
\text { IC50 } \mu \mathrm{g} / \mathrm{ml}\end{array}$ \\
\hline Chloroform & $54.42 \pm 0.77$ & $13.89 \pm 0.03$ & $29.67 \pm 0.17$ & $96.93 \pm 2.65$ & $68.0 \pm 0.01$ \\
\hline n-butanol & $11.11 \pm 0.22$ & $4.99 \pm 0.06$ & $8.95 \pm 0.03$ & $42.33 \pm 0.31$ & $5.29 \pm 0.04$ \\
\hline Compound 2 & $9.10 \pm 0.00$ & $11.46 \pm 0.00$ & $20.87 \pm 0.64$ & $45.67 \pm 3.30$ & / \\
\hline Compound 3 & $6.77 \pm 0.09$ & $10.63 \pm 0.12$ & $15.02 \pm 0.47$ & $22.87 \pm 0.29$ & / \\
\hline \multicolumn{6}{|l|}{ Standards } \\
\hline BHT $(1 \mu \mathrm{g} / \mu \mathrm{l})$ & $22.32 \pm 1.19$ & $1.29 \pm 0.30$ & $9.62 \pm 0.87$ & $>50$ & $1.05 \pm 0.01$ \\
\hline Ascorbic acid $(1 \mu \mathrm{g} / \mu \mathrm{l})$ & & & & $9.01 \pm 1.46$ & \\
\hline Ascorbic acid $(4 \mu \mathrm{g} / \mu \mathrm{l})$ & & & & $6.77 \pm 1.15$ & \\
\hline Tannic acid $(4 \mu \mathrm{g} / \mu \mathrm{l})$ & & & & $5.39 \pm 0.91$ & \\
\hline$\alpha$-tocopherol $(4 \mu \mathrm{g} / \mu \mathrm{l})$ & & & & $34.93 \pm 2.38$ & \\
\hline
\end{tabular}

*Values were expressed are means \pm SD. Of three parallel measurements, (p<0.05). SD: Standard deviation, C. azarolus: Crataegus azarolus, BHT: butyl hydroxyl toluene, BHA: Butyl hydroxyl anisole, DPPH: 2,2-diphenyl-picrylhydrazyl, ABTS: 2,2'-azino-bis-(3-ethylbenzothiazoline-6-sulfonic acid, IC50: Half maximal inhibitory concentration

mixture. Immediately, the absorbance at zero time $\left(A_{0}\right)$ was measured at $470 \mathrm{~nm}$ using a 96-well microplate reader. The plate was incubated at $50^{\circ} \mathrm{C}$ for $2 \mathrm{~h}$, and then, the absorbance $\left(\mathrm{A}_{\mathrm{t}}\right)$ of the mixture was measured again at $470 \mathrm{~nm}$. BHA and BHT were used as antioxidant standards. Ethanol was used as the blank solution (Table 2). The bleaching rate of $\beta$-carotene was calculated according to the equation:

$\mathrm{R}=\ln \left(\mathrm{A}_{0} / \mathrm{A}_{\mathrm{t}}\right) / \mathrm{t}$

Where, $A_{0}$ and $A_{t}$ are absorbance at time zero and $t=120 \mathrm{~min}$, ln is the natural logarithm. The antioxidant activity was calculated in terms of percentage inhibition relative to the blank using the equation:

$\%$ Antioxidant activity $=\left[\left(\mathrm{R}_{\text {blank }}-\mathrm{R}_{\text {sample }}\right) / \mathrm{R}_{\text {blank }}\right] \times 100$

Statistical analyses

All the experimental results are mentioned as a mean \pm standard deviation of three trials.

\section{RESULTS AND DISCUSSION}

\section{Phytochemical contents}

The structures of the flavonoid glycosides 1, 2, and 3 (fig. 1) isolated from the n-butanol extract were identified by spectral analysis (ultraviolet [UV], ${ }^{1} \mathrm{H}$, and ${ }^{13} \mathrm{C}$-nuclear magnetic resonance [NMR]), acid hydrolysis and by comparison with literature data:

Quercetin-3-O- $\beta$-galactoside (1): Yellow powder, UV $(\lambda, \mathrm{nm})$ : $\mathrm{MeOH} 256$ 268sh 361, +NaOH 370327 410, + $\mathrm{AlCl}_{3} 273$ 298sh 430, + HCl 267 310sh 400, NaOAc $275317 \mathrm{sh} 372,+\mathrm{H}_{3} \mathrm{BO}_{3} 262326 \mathrm{sh} 380 .{ }^{1} \mathrm{H}-\mathrm{NMR}(400 \mathrm{MHz}$, DMSO- $\left.d_{6}, \delta, \mathrm{ppm}\right): 7.6\left(1 \mathrm{H}, d d, 8,2 \mathrm{~Hz}, \mathrm{H}-6^{\prime}\right), 7.48\left(1 \mathrm{H}, d, 2 \mathrm{~Hz}, \mathrm{H}-2^{\prime}\right)$, $6.75\left(1 \mathrm{H}, d, 8.8 \mathrm{~Hz}, \mathrm{H}-5^{\prime}\right), 6.26(1 \mathrm{H}, d, 2 \mathrm{~Hz}, \mathrm{H}-8), 6.06(1 \mathrm{H}, d, 2 \mathrm{~Hz}, \mathrm{H}-6)$, $5.29\left(1 \mathrm{H}, d, 7.6 \mathrm{~Hz}, \mathrm{H}-1^{\prime \prime}\right), 3.1-3.9\left(6 \mathrm{H}, m\right.$, protons of galactose). ${ }^{13} \mathrm{C}$-NMR (100 MHz, DMSO- $\left.d_{6}, \delta, \mathrm{ppm}\right): 177.0$ (C-4), 161.0 (C-7), 156.5 (C-5), 155.8 (C-9), 154.0 (C-2), 148.8 (C-4'), 144.9 (C-3'), 133.3 (C-3), 121.8 (C-6'), 120.8 (C-1'), 115.7 (C-5'), 115.2 (C-2'), 102.1 (C-1', C-10), 99.3 (C-6), 93.8 (C-8), 75.8 (C-5”), 73.2 (C-3”), 71.2 (C-2”), 67.9 (C-4”), 60.1 (C-6").

Quercetin-3-O- $\beta$-glucoside (2): Yellow powder, UV $(\lambda, \mathrm{nm})$ : $\mathrm{MeOH} 257$ 270 sh 359, +NaOH 271327 409, + AlCl $_{3}$ 275 300sh 434, +HCl 269300363 $402,+\mathrm{NaOAc} 274$ 318sh 394, $+\mathrm{H}_{3} \mathrm{BO}_{3} 264318 \mathrm{sh} 382 .{ }^{1} \mathrm{H}-\mathrm{NMR}(250 \mathrm{MHz}$,
$\left.\mathrm{CD}_{3} \mathrm{OD}, \delta, \mathrm{ppm}\right): 7.83\left(1 \mathrm{H}, d, 2.1 \mathrm{~Hz}, \mathrm{H}-2^{\prime}\right), 7.59\left(1 \mathrm{H}, d d, 8.4,2.1 \mathrm{~Hz}, \mathrm{H}-6^{\prime}\right)$, $6.88\left(1 \mathrm{H}, d, 8.4 \mathrm{~Hz}, \mathrm{H}-5^{\prime}\right), 6.41(1 \mathrm{H}, d, 1.5 \mathrm{~Hz}, \mathrm{H}-8), 6.21(1 \mathrm{H}, d, 1.5 \mathrm{~Hz}$, $\mathrm{H}-6), 5.18(1 \mathrm{H}, d, 7.5 \mathrm{~Hz}, \mathrm{H}-1$ '), 3.3-4.0 (6H, $m$, protons of glucose).

Quercetin-3-O-rutinoside (3): Yellow powder, UV $(\lambda, \mathrm{nm})$ : $\mathrm{MeOH} 257$ 269sh 360, +NaOH 272329 413, + $\mathrm{AlCl}_{3} 275$ 300sh 434, + HCl 269 364sh 401, +NaOAc 274322 390, + $\mathrm{H}_{3} \mathrm{BO}_{3} 264390 .{ }^{1} \mathrm{H}-\mathrm{NMR}(250 \mathrm{MHz}$, $\left.\mathrm{CD}_{3} \mathrm{OD}, \delta, \mathrm{ppm}\right): 7.87\left(1 \mathrm{H}, d, 1.5 \mathrm{~Hz}, \mathrm{H}-2^{\prime}\right), 7.60$ (1H, $d d, 8.4,1.5 \mathrm{~Hz}, \mathrm{H}-6^{\prime}$ ), $6.9\left(1 \mathrm{H}, d, 8.4 \mathrm{~Hz}, \mathrm{H}-5^{\prime}\right), 6.4(1 \mathrm{H}, d, 1.5 \mathrm{~Hz}, \mathrm{H}-8), 6.2(1 \mathrm{H}, d, 1.5 \mathrm{~Hz}, \mathrm{H}-6)$, $5.1\left(1 \mathrm{H}, d, 7.8 \mathrm{~Hz}, \mathrm{H}-1^{\prime \prime}\right), 4.5$ (1H, br.s, H-1"'), 1.1 (3H, d, $\left.5.7 \mathrm{~Hz}, \mathrm{H}-6^{\prime \prime \prime}\right)$, 3.3-4.0 (10H, $m$, protons of glucose and rhamnose).

Compounds 1-3 were obtained as a yellow powder and their chromatographic behavior indicated that are flavonoid glycosides. The UV-visible spectra in $\mathrm{MeOH}$ and with reagents revealed the presence of quercetin skeleton as aglycone for the three compounds by the presence of free $\mathrm{OH}$ groups at positions 5, 7, 3', and 4' and the presence of a substituted hydroxy group in position 3 .

The nature of glycosidic moiety of the compounds was determined by acid hydrolysis with $2 \mathrm{~N} \mathrm{HCl}$ at $100^{\circ} \mathrm{C}$ for 30 min of compounds 1 and 2 which gave galactose and glucose, respectively, while compound 3 gave glucose and rhamnose [22-24]. The sugars were identified by co-TLC on silica gel with authentic samples, using acetone- $\mathrm{H}_{2} \mathrm{O}(9: 1)$ as eluent and aniline malonate as detection reagent. The ${ }^{1} \mathrm{H}-\mathrm{NMR}$ spectra of the three compounds showed the existence of five aromatic protons: $\mathrm{H}_{2}{ }^{\prime}(1 \mathrm{H}, d$, $\mathrm{J}=2 \mathrm{~Hz}), \mathrm{H} 5^{\prime}(1 \mathrm{H}, d, \mathrm{~J}=8.5 \mathrm{~Hz}), \mathrm{H} 6^{\prime}(1 \mathrm{H}, d d, \mathrm{~J}=8.5,2 \mathrm{~Hz})$ for B-ring and two meta-coupled protons $\mathrm{H} 6(1 \mathrm{H}, d, \mathrm{~J}=2 \mathrm{~Hz})$ and $\mathrm{H} 8(1 \mathrm{H}, d, \mathrm{~J}=2 \mathrm{~Hz})$ for A-ring, characteristic of a quercetin aglycone.

In addition, the ${ }^{1} \mathrm{H}-\mathrm{NMR}$ spectrum of compounds 1 showed the presence of an anomeric proton H1" $(1 \mathrm{H}, \mathrm{d}, \mathrm{J}=7.6 \mathrm{~Hz})$ at $\delta 5.29$ and a bulk of six other protons between 3.1 and 3.9 ppm confirmed the presence of galactosyl moiety. Finally, the structure of compound 1 was confirmed by its ${ }^{13} \mathrm{C}$-NMR spectrum that gave characteristic peaks of quercetin-3-0galactoside compared to literature data $[25,26]$. The ${ }^{1} \mathrm{H}-\mathrm{NMR}$ spectrum of compound 2 revealed the presence an anomeric proton $\mathrm{H} 1$ " $(1 \mathrm{H}$, $\mathrm{d}, \mathrm{J}=7.5 \mathrm{~Hz}$ ) at $\delta 5.18$ attributed to glucosyl moiety and a bulk of six other protons between 3.3 and $4.0 \mathrm{ppm}$ which confirm the structure of compound 2 as quercetin-3-0-glucoside [26]. The1H-NMR spectrum of compound 3 showed the existence of two anomeric protons, the first $(1 \mathrm{H}, d, \mathrm{~J}=7.8 \mathrm{~Hz})$ at $\delta 5.1$ attributed to glucose (H1") at position 3 and the second $(1 \mathrm{H}$, br. $S$ ) for rhamnose (H1'”) at $\delta 4.5$ with the 


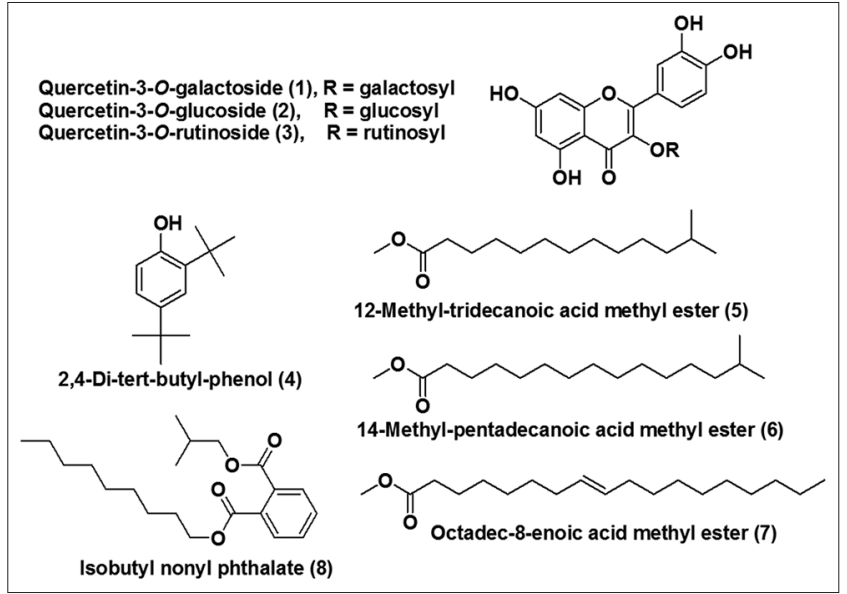

Fig. 1: Chemical structures of identified compounds 1-8

characteristic signal ( $3 \mathrm{H}, d, \mathrm{~J}=5.7 \mathrm{~Hz}$ ) at $\delta 1.1$ of their methyl ( $\mathrm{H} 6$ '”). The upfield of H1"' indicated that rhamnose is a terminal sugar. The linkage of rhamnose to position 6 of glucose was deduced by comparison of our data with the literature $[24,26]$. The structure of compound 3 was confirmed to be quercetin-3-0-rutinoside.

Moreover, the compounds 4-8 were identified by comparison of their mass spectra obtained by GC/MS analysis with literature data (NIST library) to be 2,4-bis (1,1-dimethyl ethyl)-phenol (4), tridecanoic acid 12-methyl-methyl ester (5), pentadecanoic acid 14-methyl-methyl ester (6), 8-octadecanoic acid methyl ester (7), and isobutyl nonyl phthalate (8) as shown in Fig. 1. Compounds 4-8, which are volatile compounds are reported for the first time from the Crataegus genus.

\section{Total phenolic and TFC}

The estimation of TPC and TFC using methods described above indicates that $C$. azarolus was very rich in phenolic and flavonoid compounds (Table 1). The TPC and TFC of the n-butanol extract reached $30.7 \%$ (expressed as GAE) and $14.3 \%$ (expressed as QE) of the weight of extract, respectively, and were largely higher than chloroform extract contents. Furthermore, the TPC and TFC values, in this study, are well above the values reported in other studies $[7,8]$ about the species, which can be explained by the difference in the period and region of plant collection and the method of extraction.

\section{Antioxidant activity}

Fruits and vegetables are highly potent antioxidants, easily available, inexpensive, and more reliable than any synthetic marketed medicament do not have side effects and possess high safety index. Many research studies have confirmed the importance of antioxidants from plants [27]. In this study, it was necessary to evaluated $C$. azarolus extracts through several tests to get more informative results on its antioxidant potential. It was necessary to evaluate its extracts through several tests. Consequently, the antioxidant activity was carried out using five different assays: DPPH free radical scavenging, ABTS cation radical decolorization, CUPRAC, reducing power activity, and $\beta$-carotene bleaching activity. The results in Table 2 revealed that the n-butanol extract was more potent than the $\mathrm{CHCl}_{3}$ extract with all used assays. This is evident for n-butanol extract because there is a close relationship between the phenolic and flavonoid contents and the antioxidant activity. The results in Table 2 confirmed that compound $\mathbf{3}$ was the most active compared to compound 2 with almost used methods. In addition, $\mathrm{IC}_{50}$ values for the n-butanol extract and compound $\mathbf{3}$ were in generally close to those of used standards. This finding is in agreement with other studies about other species of Crataegus genus collected in other countries [7,9,28,29].

\section{CONCLUSION}

We report, herein, for the first time, the identification of five volatile compounds (4-8) from the aerial parts of C. azarolus (Rosaceae) by GC-MS. From obtained results, the highest level of TPC and TFC was found in the n-butanol extract. The antioxidant activities of the chloroform, n-butanol extracts, and the pure compounds 2 and 3 have been determined using five assays. The n-butanol extract shown a powerful antioxidant activity, which can be ascribed to its richest in phenolic compounds. However, further studies are required to isolate other phytochemical constituents and subjecting it to biological evaluation.

\section{ACKNOWLEDGMENTS}

This study was supported by Algerian Ministry of Higher Education and Scientific Research.

\section{CONFLICTS OF INTERESTS}

All authors have none to declare.

\section{REFERENCES}

1. Donmez AA. The genus Crataegus L. (Rosaceae) with special reference to hybridization and biodiversity in Turkey. Turk J Bot 2004:28:29-37.

2. Said O, Khalil K, Fulder S, Azaizeh H. Ethnopharmacological survey of medicinal herbs in Israel, the Golan heights and the west bank region. J Ethnopharmacol 2002;83:251-65.

3. Chang Q, Zuo Z, Harrison F, Chow MS. Hawthorn. J Clin Pharmacol 2002;42:605-12.

4. Chemical Industry Press. State pharmacopoeia commission of the people's republic of China. Pharmacopoeia of the People's Republic of China. $8^{\text {th }}$ ed. Beijing: Chemical Industry Press; 2005.

5. The Council of Europe. European pharmacopoeia. $5^{\text {th }}$ ed. Strasbourg, France: European Directorate for the quality of Medicines (EDQM); 2005.

6. Quezel P, Santa S. Nouvelle flore de l'Algérie et des régions désertique méridionales. Tome 2. Paris: CNRS; 1963. p. 459.

7. Bahri-Sahloul R, Ammar S, Fredj RB, Saguem S, Grec S, Trotin F, et al. Polyphenol contents and antioxidant activities of extracts from flowers of two Crataegus azarolus L. Varieties. Pak J Biol Sci 2009;12:660-8.

8. Bahri-Sahloul R, Ammar S, Grec S, Skhiri FH. Chemical characterization of Crataegus azarolus (L.) fruit from 14 genotypes found in Tunisia. J Hortic Sci Biotech 2009;84:23-8.

9. Belkhir M, Rebai O, Dhaouadi K, Congiu FG, Tuberoso CI, Amri M, et al. Comparative analysis of Tunisian wild Crataegus azarolus (yellow azarole) and Crataegus monogyna (red azarole) leaf, fruit, and traditionally derived syrup: Phenolic profiles and antioxidant and antimicrobial activities of the aqueous-acetone extracts. J Agric Food Chem 2013;61:9594-601.

10. Belkhir M, Rebai O, Dhaouadi K, Sioud B, Amri M, Fattouch S. Antioxidant and antimicrobial activities of Tunisian azarole (Crataegus azarolus L.) leaves and fruit pulp/peel polyphenolic extracts. Indian J Food Prop 2013;16:1380-93.

11. Lakache Z, Tigrine-Kordjani N, Tigrine C, Kameli A, Meklati BY. Volatile constituents, phenolic compounds and antioxidant activity of Crataegus azarolus leaves and flowers growing in Algeria. Chem Nat Comp 2014;50:1132-5.

12. Singleton VL, Orthofer R, Lamuela-Raventos RM. Analysis of total phenols and other oxidation substrates and antioxidants by means of Folin-Ciocalteu reagent. Methods Enzymol 1999;299:152-78.

13. Turkoglu A, Duru ME, Mercan N, Kivrak I, Gezer K. Antioxidant and antimicrobial activities of Laetiporus (Bull.) Murrill. Food Chem 2007;101:267-73.

14. Sakat S, Juvekar AR, Gambhire MN. In vitro antioxidant and antiinflamatory activity of methanol extract of Oxalis corniculata Linn. Int J Pharm Pharm Sci 2010;2:146-55.

15. Indu $\mathrm{H}$, Seenivasan R. In vitro antioxidant activity of selected seaweeds from southeast coast of India. Int J Pharm Pharm Sci 2013;5:474-84.

16. Blois MS. Antioxidant determinations by the use of a stable free radical. Nature 1958;26:1199-200.

17. Tel G, Apaydin M, Duru ME, Öztürk M. Antioxidant and cholinesterase inhibition activities of three Tricholoma species with total phenolic and flavonoid contents: The edible Mushrooms from Anatolia. Food Anal Methods 2012;5:495-504.

18. Re R, Pellegrini N, Proteggente A, Pannala A, Yang M, Rice-Evans C. Antioxidant activity applying an improved ABTS radical cation decolorization assay free radical. Bio Med 1999;26:1231-7. 
19. Apak R, Guclu K, Ozyurek M, Karademir SE. Novel total antioxidant capacity index for dietary polyphenols and vitamins $\mathrm{C}$ and $\mathrm{E}$ using their cupric ion reducing capability in the presence of neocuproine: CUPRAC. Method J Agric Food Chem 2004;52:7970-81.

20. Oyaizu M. Studies on products of browning reactions: Antioxidative activities of browning reaction prepared from glucosamine. Jpn J Nutr 1986;44:307-15.

21. Marco GJ. A rapid method for evaluation of antioxidants. J Am Oil Chem Soc 1968;45:594-8.

22. Harborne JB, Mabry TJ, Mabry H. The Flavonoids. London: Chapman and Hall; 1975.

23. Markham KR. Techniques of Flavonoids Identification. London: Academic Press; 1982.

24. Mabry TJ, Markham KR, Thomas MB. The systematic identification of flavonoids. New York: Springer-Verlag; 1970.
25. Markham KR, Chari VM. The Carbon 13-NMR Spectroscopy of Flavonoids (In flavonoids: Advances in research). London: Chapman and Hall; 1982.

26. Markham KR, Geiger H. 1H NMR spectroscopy of flavonoids and their glycosides in DMSO-d6, (In The Flavonoids: Advances in research since 1986). London: Chapman and Hall; 1994.

27. Mayura AK, Suparna MB, Pratima K. Role of antioxidants and nutrition in oxidative stress. Int J App Pharm 2015;7:1-4.

28. Bignami C, Paolocci M, Scossa A, Bertazza G. Preliminary evaluation of nutritional and medicinal components of Crataegus azarolus fruits. Acta Hort 2003;597:95-100.

29. Bahorun T, Aumjaud E, Ramphul H, Rycha M, Luximon-Ramma A, Trotin F, et al. Phenolic constituents and antioxidant capacities of Crataegus monogyna (Hawthorn) callus extracts. Nahrung 2003;47:191-8. 